WIELKIE TEMATY KULTURY W LITERATURACH SKOWIAŃSKICH

Slavica Wratislaviensia CLXVIII • Wrocław 2019•AUWr No 3875

DOI: 10.19195/0137-1150.168.50

Data przesłania artykułu: 12.09 .2017

Data akceptacji artykułu: 4.12.2017

ANNA MODELSKA-KWAŚNIOWSKA

Uniwersytet Opolski, Polska

\title{
Śmierć, nieobecność i samotność - motyw traumatyzującej utraty matki w zbiorze opowiadań Lejli Kalamujić Zovite me Esteban
}

Lejla Kalamujić to urodzona w Sarajewie w 1980 roku prozaiczka średniego pokolenia, aktywnie współtworząca bogaty i barwny krajobraz współczesnej literatury w Bośni i Hercegowinie, określanej przez Damira Arsenijevicia jako književnost nakon genocida ${ }^{1}$. Wpisuje się jednocześnie w charakterystyczne dla współczesnej kobiecej prozy w Bośni trendy, w tym przede wszystkim: wybór małej formy (dotąd publikowała krótkie opowiadania), co ma być wyrazem odrzucenia wielkiej opowieści (otpor velikoj priči) jako nieodpowiedniej i nieodpowiadającej potrzebom oraz możliwościom współczesnej literatury². W 2009 roku Kalamujić wydała debiutancki tom opowiadań Anatomija osmijeha. Opublikowany sześć lat później zbiór Zovite me Esteban (2015) wzbudził duże zainteresowanie, w 2015 roku wyróżniono go Nagrodą im. Edo Budiša za najlepszy zbiór opowiadań, a w 2016 roku książka była jednym z bośniacko-hercegowińskich kandydatów do Europejskiej Nagrody Literackiej przyznawanej w Londynie, co wskazuje na jej wysoką pozycję w lokalnym życiu literackim.

Tom Zovite me Esteban składa się z dziewiętnastu tematycznie powiązanych opowiadań, wpisujących się w nurt prozy intymistycznej. W kolejnych tekstach autorka przywołuje najbardziej znaczące przeżycia oraz doświadczenia (śmierć matki, wojna domowa i rozdzielenie rodziny, stopniowe odchodzenie kolejnych bliskich, czego konsekwencją jest rozpad dotychczasowego świata i kryzys psychiczny narratorki) i używając różnych form podawczych (między innymi list),

${ }^{1}$ D. Arsenijević, Ljubav nakon genocida, http://sveske.ba/en/content/ljubav-nakon-genocida [dostęp: 25.03.2017].

${ }^{2}$ Zabilježene, red. E. Bošnjak, S. Gavrić, Sarajevo 2014. 
portretuje samą siebie. Zastosowanie narracji pierwszoosobowej zbliża utwory do zapisów pamiętnikowych. Czas nie jest elementem porządkującym opowieść, jest nim raczej ewolucja bohaterki, proces jej dorastania i przezwyciężania traum, które naznaczyły jej biografię. Narratorka swobodnie wędruje w czasie, a opowieść konstruowana jest z różnych perspektyw; w wielu utworach opisywane są wspomnienia dziecka lub nastolatki, jednak na ten obraz rzeczywistości zwykle nakłada się perspektywa dorosłej kobiety, która formułuje pewne wnioski i komentarze.

Charakterystyczną cechą opowiadań zebranych w tomie Zovite me Esteban jest autobiografizm. Pisanie traktowane jest przez bez mała trzydziestoletnią narratorkę będącą alter ego pisarki, noszącą nawet jej imię, Lejla, jako terapia mająca pomóc jej przezwyciężyć kryzys psychiczny i egzystencjalny. Jej biografia naznaczona jest przede wszystkim utratą, stanowiącą jeden temat rozpisany na wiele opowieści. Utrata matki ${ }^{3}$, następnie wybuch wojny domowej i zniszczenie świata, który znała i kochała, potem: śmierci kolejnych bliskich osób, dziadków sprawiają, że ostatecznie, nie umiejąc odnaleźć się w rzeczywistości, trafia na leczenie do szpitala psychiatrycznego.

W opowiadaniu Buka, bijes i ona pisze: „Riječima crtam jedan izgubljeni svijet”, natomiast w jednym z wywiadów autorka wyjaśnia swój sposób rozumienia literatury i własnego pisarstwa następująco: „Ja mislim da svaka osoba gradi svoje mjesto u svijetu putem vlastitog poimanja fikcije i fakcije. Meni je to temeljno određenje. U mom slučaju ja svoju »fakciju« mogu izraziti samo putem »fikcije« i obrnuto"s. Kalamujić swobodnie przekracza granice między życiem a literaturą. Robi to także licznymi odniesieniami intertekstualnymi, gdy sięga po dzieła autorów, którzy mieli w jakimś sensie podobne do niej doświadczenia (na przykład Albert Camus, którego ojciec zginął, gdy przyszły noblista był

${ }^{3} \mathrm{~W}$ żadnym z opowiadań nie pojawia się informacja na temat okoliczności śmierci matki narratorki. W prywatnej korespondencji, wyrażając zgodę na upublicznienie swej opowieści na potrzeby niniejszego artykułu, pisarka przedstawiła mi tę historię następująco:

„Moja je majka umrla iznenada. Iako, nekoliko godine prije smrti, imala je manjih problema sa srcem. Navodno je i pila lijekove. Ali niko nije pretpostavljao da bi to moglo biti fatalno. Meni su kasnije pričali, da su joj problemi sa srcem prestali kad sam se ja rodila. I tako je bilo dvije godine. U tom periodu je prestala piti lijekove. I onda je došla ta noć. Četiri dana poslije mog rođendana. Ona i ja smo bile same u stanu. Ja u kolijevci, a ona je sjedila u fotelji i pušila cigaru. Umrla je tokom noći od infarkta. Pronašli su je u tom sjedećem položaju narednog dana. I mene naravno, koja sam bila u kolijevci. U pepeljari joj je ostala do pola izgorena cigareta. To je ono kako su meni kasnije pričali”.

Fakt, że śmierć mamy, bardzo młodej, bo zaledwie dwudziestodwuletniej kobiety, była nagła, rzuca światło na to, jak jej odejście wpłynęło na całą rodzinę: ojciec dziewczynki, nie mogąc otrząsnąć się z rozpaczy, wpadł w alkoholizm, dziadkowie próbowali otoczyć ją miłością i zastąpić jej de facto oboje rodziców, czyniąc jednocześnie ze śmierci jej matki głęboko skrywaną tajemnicę - prawdę o jej odejściu poznała dopiero po kilku latach.

${ }^{4}$ L. Kalamujić, Zovite me Esteban, Beograd 2016, s. 67.

5 S. Marić, Lejla Kalamujić Moje teme su seksualnost, ludilo i smrt, http://www.strane.ba/ lejla-kalamujic-moje-teme-su-seksualnost-ludilo-i-smrt/ [dostęp: 9.05.2017]. 
rocznym dzieckiem; Elizabeth Bishop wychowywana przez dziadków w wyniku wczesnego osierocenia przez rodziców). Pisanie pełni zatem funkcję terapeutyczną, a jednocześnie autentyczność sztuki warunkuje właśnie ów Kišowski „gorzki osad doświadczenia"6 który stanowi istotę prozy bośniackiej autorki.

Jednym z głównych motywów w utworze jest autobiograficzne poszukiwanie matki. Narratorka doświadcza raczej poczucia jej nieobecności niż tęsknoty, ponieważ $\mathrm{w}$ istocie nie zdążyła nawet $\mathrm{z}$ mamą nawiązać pogłębionej więzi ${ }^{7}$. Brak matki powoduje z jednej strony jej poszukiwanie, próbę udzielenia odpowiedzi na pytania o to, jaka była i jak wyglądałoby wspólne życie oraz relacja matka-córka, z drugiej także zaprzeczanie, negowanie przez narratorkę faktu, że doświadczyła straty, wypieranie traumatycznych doświadczeń jest bowiem formą obrony psychiki przed cierpieniem.

Relacja matka-córka uznawana jest za najsilniejszą i jednocześnie najbardziej skomplikowaną relację międzyludzką. Jej ważność i specyfika akcentowana była zwłaszcza przez drugą falę feminizmu, czyli od lat sześćdziesiątych XX wieku. Adrienne Rich obok pojęcia „macierzyństwo” (które zresztą, podobnie jak część feministek radykalnych, rozszerzała poza fakt biologicznego bycia czyjąś matką) wprowadziła pojęcie „,córkostwo”8 i podkreślała, że „Utrata matki przez córkę i córki przez matkę jest podstawową kobiecą tragedią" ". Rich sięgnęła do mitu o Demeter i Korze jako metafory sytuacji matki i córki, podkreślając, że „Oddzielenie Demeter od Kory jest niechciane; nie wynika ani z buntu córki przeciwko matce, ani z odrzucenia córki przez matkę"10, co według amerykańskiej feministki wskazuje jednoznacznie na fakt, że związki miedzy matką a córką były szczególnie złożone oraz zagrożone już w czasach przedpiśmiennych ${ }^{11}$.

$\mathrm{W}$ opowiadaniach zebranych $\mathrm{w}$ tomie Zovite me Esteban występuje kilka par matek i córek (Lejla i Snežana, Snežana i Brana, babka Lejli, a także Sofka Nikolić i Marica); dla wszystkich historii charakterystyczna jest przedwczesna śmierć jednej z kobiet, brutalne przerwanie relacji bądź, jak w przypadku Lejli i Snežany, wręcz niemożność nawiązania świadomej relacji.

Narratorka straciła matkę, gdy miała dwa lata, przy czym prawdę o tym, co się wydarzyło, poznała, dopiero gdy była pięcioletnim dzieckiem. Śmierć stanowiła w rodzinie Lejli tabu, o czym świadczy przede wszystkim fakt, że przez kilka lat nie powiedziano jej prawdy o odejściu matki, a dziadkowie ukrywali przed nią

${ }^{6}$ D. Kiš, Gorzki osad doświadczenia, [w:] idem, Życie, literatura, wyb. i przeł. D. Cirlić-Straszyńska, posłowie M. Miočinović, Izabelin 1999, s. 8.

${ }^{7}$ H. Edelman, Córki, które zostały bez matki. Dziedzictwo straty, na podst. przekł. P. Duchera tekst oprac. D. Rossowski, Łódź 2011, s. 77-78.

${ }^{8}$ W literaturze przedmiotu funkcjonuje również bliskie pojęcie „,córectwo” (daughterhood) oznaczające związek pokrewieństwa kobiet z rodzicami (M. Humm, Słownik teorii feminizmu, przeł. J. Mikos. B. Umińska, Warszawa 1993, s. 37).

${ }^{9}$ A. Rich, Zrodzone z kobiety. Macierzyństwo jako doświadczenie i instytucja, przeł. J. Mizielińska, Warszawa 2000, s. 326.

${ }^{10}$ Ibidem, s. 329.

11 Ibidem. 
wszystko, co w jakikolwiek sposób było związane ze śmiercią, na przykład chowali zabite przez koty gołębie, starając się zapewne zapobiec pogłębianiu traumy dziewczynki: „Smrt [...] krili su od mene kao zmija noge. Sahranjivali bi mrtve golubove u bašti i prekrivali svježe razrovanu zemlju lišćem" ${ }^{2}$. Tymczasem okazuje się, że taki sposób postępowania wcale nie odnosi zamierzonych skutków:

Wydaje się oczywiste, że im powszechniejsze są zabiegi separowania człowieka od realnego doświadczenia śmierci, tym mniej jest okazji doświadczania niepokoju. [...] Jest tu jednak jeden ukryty paradoks: separując się od śmierci, rzadziej przeżywamy lęk, ale jeśli już go przeżywamy, to silniejszy ${ }^{13}$,

twierdzi psycholog Wiesław Łukaszewski. Obserwacja ta znajduje potwierdzenie w historii Lejli.

Tabuizowanie śmierci skutkuje ponadto niedokończeniem żałoby po utraconej matce, której Lejla nie przeżywa we właściwy sposób, co z kolei sprawia, że historia jej cierpienia jest tłumiona i wciąż niewyrażona, a po traumatycznej utracie pozostaje lęk ${ }^{14}$. Prowadzi to do poważnych problemów w późniejszym wieku, także w dorosłości, takich jak: depresja, mocne poczucie winy, chaosu i dezorientacji życiowej, a także niepokojące obsesje ${ }^{15}$, których narratorka doświadcza przez wiele lat (na przykład nieustanne kontrolowanie, czy bliska osoba, człowiek, a nawet kot, oddycha albo - czy oddycha we „właściwy” sposób: czy jej oddech nie jest zbyt szybki albo zbyt powolny). Odczuwa chorobliwy lęk przed utratą kolejnych bliskich osób, co sprawia, że boi się nawiązywać nowe bliskie relacje. Według teorii traumy człowiek wskutek traumatyzujących przeżyć traci kontakt z sobą i w związku z tym nie potrafi we właściwy sposób pojmować świata zewnętrznego, czego efektem jest nieumiejętność wchodzenia w zdrowe relacje $\mathrm{z}$ innymi ludźmi ${ }^{16}$.

Istotnym czynnikiem wpływającym na sposób przeżywania śmierci matki, a następnie innych bliskich osób jest też fakt, że w świecie Lejli nie istnieje sankcja religijna. Jej matka została pochowana w ateistycznej części sarajewskiego cmentarza Bare, dziadkowie ze strony matki byli niewierzący. Lejla mówi o swoim stosunku do religii: „Ja nemam odgovore"17.

Lejla początkowo przyjmuje postawę eskapistyczną, próbuje wyprzeć to, co ją spotkało. W opowiadaniu Čekajući golubove wraca pamięcią do czasów dzieciństwa, kiedy oczekiwanie na wypuszczone rankiem z klatki gołębie jest

12 L. Kalamujić, Zovite me..., s. 20.

13 W. Łukaszewski, Udręka życia, Sopot 2010, s. 40.

14 B. Janusz, Niewypowiedziane cierpienia. Międzypokoleniowy przekaz traumy, http:// www.miesecznik.znak.com.pl/7202015bernadettajanuszniewypowiedziane-cierpienia-międzypo koleniowy-przekaz-raumy/ [dostęp: 9.02.2017].

${ }_{15}$ M. Kogut, Cierpienie oczami dziecka jedynego, [w:] Pomoc człowiekowi w obliczu cierpienia i śmierci, red. J. Daszykowska, Stalowa Wola 2013, s. 176-177.

${ }^{16}$ F. Ruppert, Symbioza i autonomia. Trauma symbiotyczna i miłość bez uwikłań, Warszawa 2012, s. 86.

${ }^{17}$ L. Kalamujić, Zovite me..., s. 80. 
$\mathrm{w}$ istocie oczekiwaniem na ojca. W obrazie dzieciństwa osieroconej przez matkę dziewczynki przenikają się punkty widzenia dorosłej kobiety oraz dziecka. Dominuje tutaj przygnębiające poczucie osamotnienia, ale też — już z dorosłej perspektywy — zrozumienie sytuacji, współczucie dla ojca, który nie radzi sobie po odejściu żony. Wątek ten jest kontynuowany w opowiadaniu Uzalud je budiš, poświęconym postaci ojca i temu, jak się (nie) odnajdywał w nowej sytuacji.

W opowiadaniu Buka, bijes i ona narratorka opisuje swoją walkę o normalność, o umiejętność życia w bliskim związku z innym człowiekiem. Poczucie odpowiedzialności za drugą osobę i świadomość kruchości własnej psychiki, lęk przed kolejnym załamaniem nerwowym wywołują wiele obaw i wątpliwości dotyczących jej prawa do wchodzenia w związek. Bezsenna noc, podczas której dręczące ją obawy urastają do niebotycznych rozmiarów, przywołuje wspomnienie ilustrujące walkę Lejli o siebie, o własne życie. Z pełnym napięcia stanem emocjonalnym narratorki harmonizuje przyroda — burzliwa aura pojawia się w opowiadaniach Kalamijić niejednokrotnie, ilustrując i wzmacniając towarzyszące jej uczucia: „Oluja pojačava kakofoniju u meni”"18.

Relacja Lejli z matką jest więc naznaczona nieobecnością matki, której dziewczynka nie zna, nie ma o niej nawet własnych wspomnień. W jednym z wywiadów autorka tak wyjaśnia specyfikę sytuacji, w jakiej się znalazła, i swój stosunek do matki oraz jej śmierci:

Pokušala sam da u ovim pričama priđem motivu smrti na način kako je on oblikovao moj život od najranijih sjećanja. On, kao prvo, nije nužno raspad, nestajanje, gubljenje... Ja sam smrt u životu najprije iskusila kao način života. Za mene je moja majka živjela kroz svoju smrt. To je bila njena prisutnost. Tek kasnije, ja ću smrt percipirati kao gubitak i rastanak. Tek kad umiru njeni roditelji i roditelji mog oca, ja ću majku izgubiti na način kako su svi oni koji su je znali izgubili puno godina prije. Njihova smrt (dakle: bake, dede, nane i dede) i taj raspad jednog mikrokosmosa, podudario se i sa raspadom jedne države ${ }^{19}$.

Początkowo matka żyje dla niej przez opowieści i wspomnienia innych, głównie rodziców zmarłej, czyli dziadków Lejli. Jej matka, Snežana, w pamięci swoich bliskich istnieje jako święta, raczej obiekt kultu niż uczuć; maszyna do pisania, która jest najważniejszą po niej pamiątką, dla rodziny staje się czymś w rodzaju relikwii.

Według Hope Edelman, zajmującej się badaniem losów kobiet, które przedwcześnie straciły matkę, to, jak radzi sobie z wymogami dalszego życia drugi rodzic, determinuje długotrwałe przystosowanie dziecka ${ }^{20}$. Będąca jedynaczką Lejla nie miała naturalnego w takich sytuacjach wsparcia rodzeństwa, była skazana na samotność, którą pogłębiał fakt, że ojciec zupełnie nie radził sobie z utratą żony. Znalazła się w wyjątkowo trudnym położeniu dziecka, które utra-

18 Ibidem, s. 63.

19 E. Salčinović, Lejla Kalamujić: Ateistička parcela na Barama mi se nametnula kao nulta tačka novog vremena, http://www.oslobodjenje.ba/kun/tehnologija/lejla-kalamujic-ateisticka-parcelana-batama-mi-se-nametnula-kao-nulta-tacka-novog-vremena/160001 [dostęp: 9.05.2017].

${ }^{20}$ H. Edelman, Córki, które..., s. 16. 
ciwszy matkę, nie znajduje oparcia w pogrążonym w długotrwałej rozpaczy i nałogu alkoholowym ojcu. Rekonstrukcji przeżyć z czasów dzieciństwa towarzyszy perspektywa dorosłej kobiety, która ówczesne doświadczenia, a także sposób ich przeżywania postrzega już inaczej, dojrzale. Wówczas ujawnia się wątek konfrontacji cierpiącego wdowca ze światem zewnętrznym, z rodziną, która bezskutecznie próbuje na niego wpłynąć, o czym traktuje opowiadanie Uzalud je budiš, którego tytuł i motyw przewodni jest parafrazą znanego wiersza Branka Miljkovicia Uzalud je budim ${ }^{21}$, będącego poetycką realizacją motywu miłości przekraczającej śmierć. Parafraza L. Kalamujić wprowadza inną perspektywę: o ile u Miljkovicia podmiot liryczny zdaje sobie sprawę z daremności pragnienia przywrócenia do życia ukochanej kobiety, o tyle u bośniackiej prozaiczki to córka uświadamia ojcu tę bolesną prawdę, gdy mówi: „Uzalud je budiš”.

W opowiadaniu Uzalud je budiš znów nakładają się na siebie dwie perspektywy narracyjne: perspektywa osieroconej przez matkę dziewczynki, która nieustannie wyczekuje powrotu ojca ${ }^{22}$ spędzającego wieczory poza domem i szukającego pociechy w alkoholu oraz perspektywa młodej kobiety, która swoje doświadczenia racjonalizuje, osadzając je w kontekście literackim, dowartościowując tym samym ból ojca, i w pewien sposób usprawiedliwiając jego sposób postępowania, (nie)radzenia sobie z cierpieniem, także kosztem córki. Nadanie temu cierpieniu wartości artystycznej służy jego uwzniośleniu. Narratorka z perspektywy czasu w poetycki sposób ukazuje konsekwencje przedwczesnego odejścia matki. Utraciwszy matkę, straciła też ojca. Intertekstualne powiązanie z utworem B. Miljkovicia przez wprowadzenie zmodyfikowanego tytułu jako refrenu, a także przywołanie fragmentu poematu stanowi artystyczną ilustrację miłości ojca do matki.

Jak dowodzą badania, śmierć bliskiej osoby może być dla dziecka źródłem traumy, a objawy posttraumatyczne mogą trwać do dorosłości, a nawet przez całe życie ${ }^{23}$. Gdy brakuje kochających, troskliwych i dających oparcie rodziców, rozwój psychiczny dziecka jest zaburzony już na początku życia ${ }^{24}$. W przypadku Lejli nieobecność rodziców (fizyczna matki i psychiczna ojca) była łagodzona faktem, że dziewczynka miała czworo kochających dziadków, którzy starali się otoczyć ją miłością i opieką. Śmierć matki zyskuje na realności i istotnie narusza fundamenty jej egzystencji, dopiero gdy następuje seria kolejnych utrat: gdy po wybuchu wojny domowej rodzina zostaje rozdzielona, wraz z dziadkami ze strony matki Lejla wyjeżdża z Sarajewa, do rodziny w Serbii, opuszczając ojca i jego rodziców, z którymi mieszkała. Kolejne doświadczenia utraty wiążą się też oczywiście ściśle z faktem,

${ }^{21}$ B. Miljković, Uzalud je budim, https://www.rastko.rs/knjizevnost/umetnicka/poezija/bmiljkovic-izbor.html\#_Toc479683280 [dostęp: 1.09.2017].

22 Postać ojca odgrywa zasadniczą rolę w jednym jeszcze, niezamieszczonym w omawianym tomie opowiadaniu Dugo putovanje u noć. L. Kalamujić, Dugo putovanje u noć, https:// issuu.com/bonacasopis/docs/bona_-_final_-_17.2._821813e85e1771 [dostęp: 15.08.2017].

${ }^{23}$ M. Orwid, Trauma, Kraków 2009, s. 27-30.

${ }^{24}$ F. Ruppert, Symbioza..., s. 82. 
że wraz z dorastaniem narratorka zaczęła pojmować ostateczność i nieodwracalność śmierci (co przeciętnie ma u dziecka miejsce około dziesiątego roku życia).

Zwrot w stronę wyobraźni i sztuki odzwierciedla pragnienie rozliczenia się z przeszłością i uporządkowania swojego życia, ale też pozwala nadać osobistemu doświadczeniu głębszy, bo ponadjednostkowy sens, służy wyjściu poza sferę własnych przeżyć. Wątki intertekstualne umożliwiają jednocześnie uzyskanie czegoś w rodzaju potwierdzenia własnych doświadczeń przez zestawienie ich z przeżyciami utrwalonymi $\mathrm{w}$ dziełach sztuki przez innych artystów.

Wybór tekstów kultury (przeważają utwory literackie, pojawia się także odniesienie do filmu Pedro Almodóvara) uwarunkowany jest podobieństwem przeżyć i wspólnotą doświadczenia - albo bohaterów literackich, albo też samych pisarzy. W opowiadaniu Dobri, loši i Kafka czternastoletnia Lejla po lekturze Procesu toczy z jego autorem wyimaginowany dialog w oblężonym Sarajewie. Tłumacząc mu powód, dla którego chciała z nim pomówić: „Ti si lud! Kako si mogao to napisati? Nevin čovjek da strada. Onako. Bez razloga. Mislim, stvarno. Pa gdje to ima?!"25, w niezamierzony sposób w świecie, w którym przyszło jej żyć, odnajduje zaskakującą odpowiedź na zadawane pisarzowi pytania. Sama jak gdyby nie dostrzegała wcześniej analogii między Kafkowską fikcją i własną rzeczywistością.

Główny wątek intertekstualny występuje w tytułowym opowiadaniu Zovite me Esteban. Kalamujić przywołuje w nim dwóch Estebanów: bohatera filmu P. Almodóvara Wszystko o mojej matce oraz postać literacką, występującą w opowiadaniu Gabriela Garcíi Márqueza Najpiękniejszy topielec świata ${ }^{26}$. Filmowy Esteban, ginący w przypadkowy sposób w dniu swoich siedemnastych urodzin, budzi w Lejli zazdrość jako ten, po którym matka prawdziwie rozpaczała; Esteban Márquezowski, którego ciało zostało wyrzucone przez morze na brzeg, wywołuje u miejscowych kobiet rozpacz pomieszaną z podziwem. Dziewiętnastoletnia narratorka w opowiadaniu Zovite me Esteban utożsamia się z umarłymi ${ }^{27} \mathrm{i}$ konstruuje wizję własnej idealnej śmierci. Idealnej, czyli takiej, której towarzyszy żal i rozpacz matki tracącej swoje dziecko. Poruszający obraz wyobrażonej śmierci i eksplozji cierpienia matki wyrasta z przekonania, że łatwiej zaprojektować własną śmierć, niż przeżyć odejście bliskiej osoby, a jednocześnie pozwala wyrazić wielką tęsknotę za tym, by doświadczyć prawdziwej matczynej miłości — nawet za cenę życia.

Wojna w opowiadaniach Kalamujić zaprezentowana jest jako łańcuch wydarzeń bezpowrotnie demolujących więzi międzyludzkie i nieodwracalnie burzących dotychczasowy ład, także w rodzinnej mikroskali — zwłaszcza gdy rodzina, jak w przypadku narratorki opowiadań — jest niejednolita pod względem etnicznym. Choć — jak w utworze Od lokomotive do lokomotive — pojawiają się uwagi na

${ }^{25}$ L. Kalamujić, Zovite me..., s. 38.

${ }^{26}$ G. G. Márquez, Najpiękniejszy topielec świata, [w:] idem, Niewiarygodna i smutna historia niewinnej Erendiry i jej niegodziwej babki, przeł. C. Marrodán, Warszawa 1974, s. 49-59.

${ }^{27}$ Interesujące jest także przekroczenie granic płci, utożsamianie się narratorki z młodymi mężczyznami. Prawdopodobnie ma to związek z jej homoseksualizmem. 
temat konkretnych zmian politycznych, które zaszły w życiu mieszkańców byłej Jugosławii wraz z rozpadem państwa, to jednak konsekwencje emocjonalne tych wydarzeń zdają się dominować: negacja bliskości między ludźmi, rozdzielanie rodzin, w efekcie czego pojawia się uczucie pustki i osamotnienia. Po wyjeździe, z powodu niemożności pozostania z tymi, którzy jej potrzebują, zaczyna się obwiniać, myśleć o sobie jako o osobie, która zawiodła bliskich (dziadków) i pozwoliła im umierać w samotności, co jest źródłem nienawiści do samej siebie: „Nisam bijesna. Ima već neko vrijeme da ne mrzim ljude oko sebe, samo sebe"28. Lejla, pochodząca z rodziny niejednolitej etnicznie, doświadcza boleśnie wszystkich tych konsekwencji, co wpływa destrukcyjnie na jej nadwerężoną psychikę i ostatecznie skutkuje koniecznością hospitalizacji na oddziale psychiatrycznym.

Ramy konstrukcyjne opowiadania Umijeće gubljenja stanowi jeden z najbardziej znanych wierszy E. Bishop: One $\operatorname{Art}^{29}$. Lejla, przebywająca w szpitalu psychiatrycznym, czyni z niego punkt wyjścia do refleksji nad własnym życiem. Nawiązuje dialog z pytającą w ironiczny sposób amerykańską poetką o kondycję człowieka skazanego na nieustanną utratę tego, co dla niego najdroższe. Naznaczona już w bardzo młodym wieku śmiercią i rozpadem biografia narratorki zbliża ją do Bishop i niejako uprawnia do opisu własnych ,ćwiczeń z utraty”30.

Uwagę zwraca forma opowiadania, będącego listem do Amerykanki. Stanisław Barańczak podkreśla, że pod względem ilościowym twórczość poetycka Bishop jest skromna (co wynika głównie z typu uprawianej przez nią poezji), natomiast nie mniej ważnym elementem jej dorobku, a przy tym imponującym, jeśli idzie o objętość, jest korespondencja ${ }^{31}$. Częste pisanie listów (poetka napisała ich kilka tysięcy ${ }^{32}$ ) było z kolei spowodowane rozlicznymi podróżami i przeprowadzkami. W tym kontekście wybór formy przez narratorkę opowiadania Umijeće gubljenja wydaje się znaczącym elementem intertekstualnego dialogu z E. Bishop.

W opowiadaniu $D a$ sam te srela Lejla konstruuje wizję spotkania z matką, wyobraża sobie z nią rozmowę, jednak z założeniem, że matka przybywa tylko na chwilę, z wizytą, nie wraca na stałe. Wyobrażenie to dobrze ilustruje, jaki rodzaj więzi łączy narratorkę z matką, ilustruje to, o czym była już mowa: narratorka nie tęskni za tym, by matka uczestniczyła w jej życiu, bo nigdy tego nie zaznała. Zwięźle relacjonuje jej zmiany, jakie nastąpiły w rodzinie (ożenek ojca i fakt, że Lejla ma przyrodnie rodzeństwo) i w mieście (przekształcanie nazw ulic, fakt, że ateistyczna część sarajewskiego cmentarza Bare, w której została pochowana Snežana, nie cieszy się obecnie popularnością). Narratorka staje się niejako przewodniczką swojej mamy po nowej rzeczywistości, zachowując

${ }^{28}$ L. Kalamujić, Zovite me..., s. 17.

29 E. Bishop, 33 wiersze, wyb., przeł., wstęp i oprac. S. Barańczak, Kraków 1995.

${ }^{30}$ Nawiązuję do tytułu książki Agaty Tuszyńskiej (eadem, Ćwiczenia z utraty, Kraków 2007).

${ }^{31}$ S. Barańczak, Wstęp: kartografia bezdomności, [w:] E. Bishop, 33 wiersze..., s. 8.

32 R. Giroux, Introduction, [w:] E. Bishop, One Art, Letters, wyb. i oprac. R. Giroux, New York 1995, s. VII-IX. 
przy tym właściwy sobie (auto)ironiczny dystans — na przykład kiedy opowiada o tym, jak dziadek namawia ją, by odwiedzała jak najczęściej grób matki, zachęcając, by na wieczorne spacery zabierała tam swoje dziewczyny, bo przecież panują tam idealne warunki: cisza, spokój i unoszący się zapach kwiatów. Tą opowieścią budzi śmiech matki, podobnie jak informacją, że dziadkowie dziurę w nagrobnym wazonie zakleili gumą do żucia, a ojciec zamierza zająć się zrobieniem kwiatowej rabatki na jej grobie. Dzięki umiejętności dostrzegania detali, również całkowicie absurdalnych, Lejla czyni swoją trudną opowieść o cierpieniu i samotności znośną, udaje jej się uniknąć (nadmiaru) patosu. Na pożegnanie mówi do matki: „Možda jednog dana napišem priču o tvojoj smrti”33.

Bezpośrednią konsekwencją obcowania ze śmiercią od najmłodszych lat jest także wyczulenie Lejli na cierpienie, ból, niesprawiedliwość, a jej mocno rozwinięta empatia przekracza granice świata ludzkiego. W kilku opowiadaniach pojawia się motyw cierpiących i umierających ptaków. Ptaki giną bądź wskutek niekorzystnych warunków atmosferycznych (burza, ulewa i wichura w utworze Zašto umiru vrapci), bądź też w efekcie agresji drapieżników, kotów, jak w opowiadaniach Čekajući golubove czy Dugo putovanje u noć.

Punktem wyjścia w opowiadaniu Dugo putovanje u noć jest cierpienie dziewczynki, której ukochany gołąb o imieniu Bijela, podarunek od ojca, został zaatakowany przez kota i śmiertelnie poraniony. W ciągu długich nocnych godzin ptak umiera na jej rękach. W opowiadaniu tym, w sposób być może bardziej bezpośredni niż w innych, Lejla mówi o istocie i nieodwracalności utraty oraz o tym, jak bardzo tego rodzaju doświadczenie zmienia życie człowieka. Sytuację małej dziewczynki tracącej ukochanego gołębia w dramatycznych okolicznościach zestawia z wydarzeniami, które następują wiele lat później: ze śmiercią dziadka i reakcją jego syna, ojca narratorki: „Sad je i njemu sasvim jasno da nakon nekih noći naprosto ne svane"34. Dokonuje zatem, występującego też w innych utworach, zabiegu zmiany perspektywy, opisuje zdarzenia z różnych okresów życia, zestawiając je na podstawie pewnego rodzaju podobieństwa (na przykład przeżywanych emocji).

W zamykającym omawiany zbiór opowiadaniu Povratak među zvijezde zostaje przywołana postać A. Camusa i jego nieukończona powieść autobiograficzna Pierwszy człowiek. Wspólnota doświadczenia, jakim jest utrata rodzica w pierwszych latach życia, i bycie w wieku, jakiego ów rodzic nie dożył, zbliża Lejlę do francuskiego noblisty, powoduje, że ze zdumieniem uświadamia sobie, iż jest dużo starsza, niż była jej matka w chwili śmierci. Wyobraża sobie, że podobne uczucia musiały towarzyszyć autorowi Dżumy, osieroconemu przez ojca, gdy był rocznym dzieckiem.

Akcja opowiadania Povratak među zvijezde rozgrywa się na cmentarzu, dokąd Lejla przyprowadza swoją ukochaną, Naidę, i ostatecznie domyka swoją

${ }^{33}$ L. Kalamujić, Zovite me..., s. 54.

34 L. Kalamujić, Dugo putovanje u noć, https://issuu.com/bonacasopis/docs/bona_-_final_-_17.2._821813e85e1771 [dostęp: 15.08.2017]. 
żałobę po matce. Autobiograficzne poszukiwanie matki przez Lejlę ma znaczenie terapeutyczne: prowadzi do zakończenia żałoby, pozwala narratorce zamknąć pewien rozdział w życiu i pójść dalej. Udaje jej się przezwyciężyć samotność, w którą została wtrącona z powodu rozpadu całego dotychczasowego świata: rodziny oraz państwa. W ostatnich słowach utworu: „Vrijeme je da se ide. Vrijeme je" 35 pobrzmiewa Bułhakowskie echo, co odważnej próbie narratorki, by zacząć żyć na nowo nadaje wymiar metafizyczny.

\section{Bibliografia}

Arsenijević D., Ljubav nakon genocida, http://sveske.ba/en/content/ljubav-nakon-genocida [dostęp: 25.03.2017].

Barańczak S., Wstęp: kartografia bezdomności, [w:] E. Bishop, 33 wiersze, wyb., przeł., wstęp i oprac. S. Barańczak, Kraków 1995.

Bishop E., 33 wiersze, wyb., przeł. i oprac. S. Barańczak, Kraków 1995.

Edelman H., Córki, które zostały bez matki. Dziedzictwo straty, na podst. przekł. P. Duchera tekst oprac. D. Rossowski, Łódź 2011.

Giroux R., Introduction, [w:] E. Bishop, One Art, Letters, wyb. i oprac. R. Giroux, New York 1995.

Humm M., Stownik teorii feminizmu, przeł. J. Mikos, B. Umińska, Warszawa 1993.

Janusz B., Niewypowiedziane cierpienia. Międzypokoleniowy przekaz traumy, http://www.miesecznik.znak.com.pl/7202015bernadettajanuszniewypowiedziane-cierpienia-międzypokoleniowy -przekaz-raumy/ [dostęp: 9.02.2017].

Kalamujić L. Dugo putovanje u noć, https://issuu.com/bonacasopis/docs/bona_-_final_17.2. 821813e85e1771 [dostęp: 15.08.2017].

Kalamujić L., Zovite me Esteban, Beograd 2016.

Kiš D., Gorzki osad doświadczenia, [w:] idem, Życie, literatura, wyb. i przeł. D. Cirlić-Straszyńska, posłowie M. Miočinović, Izabelin, 1999.

Kogut M., Cierpienie oczami dziecka jedynego, [w:] Pomoc człowiekowi w obliczu cierpienia i śmier$c i$, red. J. Daszykowska, Stalowa Wola 2013.

Łukaszewski W., Udręka życia, Sopot 2010.

Marić S., Lejla Kalamujić Moje teme su seksualnost, ludilo i smrt, http://www.strane.ba/lejlakalamujic-moje-teme-su-seksualnost-ludilo-i-smrt/ [dostęp: 9.05.2017].

Márquez G. G., Najpiękniejszy topielec świata, [w:] idem, Niewiarygodna i smutna historia niewinnej Erendiry i jej niegodziwej babki, przeł. C. Marrodán, Warszawa 1974.

Miljković B., Uzalud je budim, https://www.rastko.rs/knjizevnost/umetnicka/poezija/bmiljkovicizbor.html\#_Toc479683280 [dostęp: 1.09.2017].

Orwid M., Trauma, Kraków 2009.

Rich A., Zrodzone z kobiety. Macierzyństwo jako doświadczenie i instytucja, przeł. J. Mizielińska, Warszawa 2000.

Ruppert F., Symbioza i autonomia. Trauma symbiotyczna i miłość bez uwiktań, Warszawa 2012.

Salčinović E., Lejla Kalamujić: Ateistička parcela na Barama mi se nametnula kao nulta tačka novog vremena, http://www.oslobodjenje.ba/kun/tehnologija/lejla-kalamujic-ateisticka-parcelana-batama-mi-se-nametnula-kao-nulta-tacka-novog-vremena/160001 [dostęp: 9.05.2017].

Tuszyńska A., Ćwiczenia z utraty, Kraków 2007.

Zabilježene, red. E. Bošnjak, S. Gavrić, Sarajevo 2014.

35 L. Kalamujić, Zovite me..., s. 118.

Slavica Wratislaviensia 168, 2019

(C) for this edition by CNS 


\section{Death, absence and loneliness: The motive of a traumatizing loss of a mother in the collection of stories Call me Esteban by Lejla Kalamujić}

\section{Summary}

Lejla Kalamujić (born 1980) is a Bosnian writer from Sarajevo and the author of two collections of stories: Anatomy of a Smile (2009) and Call me Esteban (2015).

The paper presents the autobiographical stories collected in the second book, in which the most important theme is death, especially the premature death of a mother. The aim of the article is to show the motive of the loss of a mother. The writer uses first-person narration and the protagonist is a woman named Lejla, a type of alter ego for her. The stories are written from different points of view and from different time perspectives.

The intertextual themes in the book are the most interesting ones and have real artistic value (there are references to be Almodóvar, Márquez, Kafka, Bishop, Miljkovic and others). The writer has a way of writing about the pain connected with death that is useful for experiencing belated mourning.

Keywords: Lejla Kalamujić, Call me Esteban, mother-daughter relationship, motive of death, women's writing in Bosna and Herzegovina

\section{Smrt, odsutnost i samoća - motiv traumatizarijućeg gubitka majke u zbirci priča Lejle Kalamujić Zovite me Esteban}

\section{Rezime}

Lejla Kalamujić (rođ. 1980) je sarajevska spisateljica koja je dosad objavila dve knjige pripovedaka: Anatomija osmijeha (2009) i Zovite me Esteban (2015). U centru pažnje ovog članka nalazi se njena druga knjiga i glavni motiv gubitka majke, dakle i majčinog odsustva u kćerkinom životu.

Kalamujićeve kratke priče pre svega karakteriše autobiografizam, a jedna od njenih glavnih tema je smrt. Spisateljica koristi naraciju u prvom licu, narratorka se zove isto kao i ona, Lejla, zatim može se reći da je autoričin alter ego. Kalamujić opisuje svoja životna iskustva bez majke iz različitih vremenskih perspektiva, zbog čega u jednoj priči ponekad vidimo zajedno perspektivu devojčice i odrasle žene.

Najinteresantnije teme u knjizi su intertekstualne (ima reference na Markesa, Kafku, Bišopa, Miljkovića i dr.) koje su pomoćna metoda pisanja o boli zbog smrti i korisne su doživljavanje zakasnele žalosti.

Ključne reči: Lejla Kalamujić, Zovite me Esteban, odnos majke i kćerke, motiv smrti, žensko pismo u Bosni i Hercegovini 